\title{
Ethnic Markets in post-Soviet Transitional Space: Their Role in Society and the Research Area
}

\author{
Victor I. Diatlov* \\ Irkutsk State University \\ 1 Karl Marx Str., Irkutsk, 664003, Russia
}

Received 12.12.2015, received in revised form 21.01.2016, accepted 02.04.2016

Open-airmarkets have become an essential element of the post-socialist transitional space. They appear over a vast area from China to Poland and Germany. Coupled with the huge scale and meaningful "shuttle trading", they formed a new phenomenon in the economic, social, political and cultural life. Markets have become a mechanism of economic survival for the vast number of people who have lost their former status and sources of income; they created the launching pad for the formation of small and medium-sized businesses. For some time they have been a key element of the supply of goods and wage, especially for low-income strata. As the first and final points of shuttle trading system, markets have integrated into the global system of relationships, not only trade ones, but socio-cultural as well.

Open-air markets have become an important area of economic activity for the cross-border migrant workers, facilitating their economic and cultural integration. In conjunction with their huge role in promoting Chinese and Turkish goods into the emerging markets, the markets have been treated in urban communities as "ethnic" markets, namely Chinese, Kyrgyz and Caucasian. As such, they quickly outgrew usual marketplaces and turned into sophisticated and self-developing social organisms, clumps of social connections, networks, conflict places, power and control mechanisms. In many Russian cities the largest ethnic and migrant clusters formed around these markets. They became "a meeting place" and a place of daily mass contacts, cooperation and conflicts; representatives of different languages, cultures and traditions. Markets have gained tremendous symbolic importance, commonly representing a lot of new forms of life, economic and cultural practices, ways of social contacts and relationships.

The end of the post-socialist era drew a line under this very role of "ethnic" markets. They have not disappeared completely, but changed themselves and change their function and place in the community. Many of the markets have been closed, the remaining ones have been marginalized and relegated to the outskirts of cities and in the periphery of economic life. They are changing their format; and on the site of the former wholesale and retail markets in the open air now there are hypermarkets, malls, etc. This does not mean the end of "ethnic business"; it is also "being rebuilt" and efficiently developing new formats and new rules of the game.

Great importance of "ethnic" markets in the era of post-socialist transitional space is paradoxically combined with weak public attention and little research. Political turmoil and social upheavals overshadowed this problem in the minds of people and in the views of researchers. The purpose of this text is to classify and organize what we know (and what we presumably do not know) about the open-air "ethnic markets" in the post-Soviet era. Perhaps this work will formulate an agenda for future research.

(C) Siberian Federal University. All rights reserved

* Corresponding author E-mail address: vikdyatlov@yandex.ru 
Keywords: ethnic markets, post-Soviet transitional space, shuttle traders, ethnic economy, crossborder migrants.

The reported study was funded by Russian Foundation for Humanities according to the research project № 16-03-00100.

DOI: 10.17516/1997-1370-2016-9-4-795-814.

Research area: politology, sociology, history.

The brightest sign of a city life in post-Soviet era was large and small, sometimes huge retail and small in volume of sold goods wholesale open-air markets. Former stadiums, closed factories, empty lots were filled with endless rows of shopping stalls, containers, hangars, factory floors, hastily adapted for trading. Thousands, sometimes tens of thousands of traders and buyers, huge flows of goods, money and services made primeval chaos at first glance, in which, as in an anthill, there were its own order, the system of influence and power, a specific logic of relationships and connections.

Markets have become an integral and extremely important part of the process of the collapse of the socialist model of society and ensuing global transformations. They occur over a vast area from China to Poland and Germany. Coupled with the huge scale and meaningful "shuttle trading", they formed a new phenomenon in the economic, social, political and cultural life.

The hypothesis of this paper is that these were vestiges of oriental bazaars and fairs, which survived the Soviet system. These were the relics of traditional markets in general. These were not even the Soviet "kolkhoz" and flea markets (rummage sales), though overgrown in size. With a certain resemblance, sometimes having genetic kinship with them, these markets were a new phenomenon. Their novelty was determined by the context of specific economic and social features in the transition period, their huge role, new people coming into stage and new relationships.
Trading in the market began to attract former Soviet people who had grown up in a society where professional market activity had not only been prohibited by the state, but also condemned by public opinion and moral. There came a lot of people without the trade experience in the past, without the appropriate traditions, values, skills and understanding. The new traders were the Soviet people, who were forced to live, work and interact in non-Soviet situation.

Markets became a mechanism of economic survival for the vast number of people who had lost their former status and sources of income. Commerce for many and perhaps most of them was at first a way of making a living, rather than the mechanism of obtaining profits. For the most adventurous, energetic, motivated and successful part of them these markets became a launching pad for doing business, being entrepreneurs in the full sense of the word.

In addition, the markets gained other functions critical to society. They became for a while a key element of the supply mechanism in the complete collapse of the socialist distribution system, having become a vitally important institution for the low-income strata of the society.

Fairly quickly the markets became certain logistic nodes of the new trading system, and almost immediately they became trans-regional and cross-border. As initial and final points of shuttle trading system, as places for forming and terminating trade flows, these markets were integrated into the global system of relationships, not only trading ones, but also socio-cultural. 
As a mechanism of promoting Chinese and Turkish goods in the emerging consumer markets, they soon started to attract economically active migrants, including cross-border ones. These markets turned into a place and a mechanism of their economic, social and cultural adaptation. The scale of this phenomenon turned out to be such that many of the markets acquired the ethnic character in urban communities, being perceived as Chinese, Kyrgyz, Caucasian.

From the citizens' point of view of, the Chinese market, for example, is a place where the Chinese people sell Chinese goods, where the Chinese language sounds and where the Chinese daily and business culture prevails. This set of features is extremely rare in other Russian conditions.

"Ethnic markets" began to play an important economic, social and symbolic role in the urban space. They quickly developed a different format, where marketplaces became sophisticated and self-developing social organisms, clumps of social connections, networks, conflicts; power and control mechanisms. Attempts to describe and understand this phenomenon evoked the debates concerning the issues of "ethnic economy" and "commercial minorities". Having appeared in other contexts, these theoretical notions are quite appropriate and heuristic here.

The concentration of foreign-language migrants from other cultures quickly made ethnic markets the major, perhaps, largest, ethnic cluster on the map of many cities, especially the Russian east ones. Unlike other not very visible clusters (hotels, hostels, for example), the markets belong to a public sphere. A lot of people constantly meet and closely communicate there. The market is a place of the ordinary and everyday contact of people from different cultures. The market is the location and the mechanism of their mutual adaptation.
From the first days of their existence, ethnic markets became a very important, discernible and discussed object of attention in the urban community; a subject of administrative decisions of the authorities at all levels and their bane accompanied by a bunch of problems and conflicts.

Markets gained tremendous symbolic importance, representing a lot of new forms of life, economic and cultural practices, ways of social contacts and relationships.

The post-Soviet era as a whole is over. Or it finishes now. A phenomenon generated by the Soviet era disappears along with it. Markets do not pass away altogether, rather they change themselves; the main thing is change in their function and place in the community. They are marginalized, edged out at the periphery, sometimes literally outflanked into the suburbs. They often simply vanish, close or radically change the format. At the site of the former wholesale and retail markets under the open sky there are now more modern formats - hypermarkets, malls, etc. Large, highly mechanized transport and wholesale businesses formed a separate sector, while open-air markets became marginal and insignificant part of the urban space and the system of economic and social relations and ties.

Markets are a dying breed... Their extinction happens almost unnoticed by the research community, almost immediately forgotten by society. It is strange, given the enormous role of the phenomenon in the transition period and its impact on the life trajectories of millions of people... This is a challenging research problem to describe and analyze the current situation, to try to reconstruct bygone past. However, the revolutionary epoch is not exercised about the archives, the preservation of historical memory. It sits well with myths. Moreover, the object under study, most of the life and activities of which was in the "gray" and sometimes "black" area did not 
seek publicity. The huge mass of information has remained unkept, not saved in the written and visual sources. The most important economic phenomenon almost did not leave a "statistically significant trace".

The apparent openness and simplicity of the construction market created an illusion, reaching research circles, that there is nothing in particular to learn, that there is no important and challenging research problem here. At the time, British anthropologists came to study Indian traders in Rhodesia and noticed a great surprise among local white people because of this. "But what can be investigated about the Indians? They sit in their little shops, inhabit their back rooms. They eat fatty foods, they are not very clean and not very honest. What else do you want to know? You can learn everything about the Indians in this country in fifteen minutes" (Dotson, Dotson, 1968, 273).

Political turmoil and social upheavals overshadowed this problem as a minor one in the minds of common people and in the views of researchers. Perhaps it is also the result of lack of interest of foreign scientists, as they literally drew up an agenda at the time of the research, so we can say they set the fashion.

The task of the study is complicated by the fact that the market is a very complex, dynamic and virtually nontransparent institution, system of connections and relationships. But this unapprehensiveness makes the problem extremely important and fascinating at the same time. The market is not just a place to trade; it is much more than an economic entity. Russian markets of the post-Soviet era are a phenomenon which is at the crossroads of several major social phenomena, and research problems respectively. Each of these problems requires special attention to research and the attention of representatives of the various sciences. Experience has shown that scientists find it difficult to interact, as it is hard to elaborate the conceptual and terminological notions, to translate from one scientific language into another. Possibly study of post-Soviet markets could make scientists find a kind of common language.

\section{Historical predecessors and historiographical tradition}

In a sense, the bazaar has always existed, it used to be and play an important role in any more or less organized and complex society. But this does not mean that it is immutable. In different historical contexts, it gets various functions, sometimes dramatically changes its internal characteristics and parameters, and varies its role in the society.

The best-known type of a market, which entered the mass mythology and became a stereotype, is, of course, "oriental bazaar". A lot of European travelers have written about, it has become a favorite kind of scenery for the European artists. It has created vivid images in fiction. Undoubtedly, the oriental bazaar is the phenomenon of a different era and a different type of society than the post-Soviet markets. This is an important, perhaps, backbone element of traditional society with the corresponding functions, place in the society, internal organization, everyday practice. Direct continuity is likely to be absent here. We therefore need important and rich historiographical tradition, the methods of analysis and learning approaches, dynamics and logic of conceptual understanding regarding traditional, especially the "eastern" markets. Capabilities of traditional study of the "bazaar" are enormous. Let us remember the classic works of F. Braudel (Braudel, 1988) and C. Geertz (Geertz, 2004).

"Kolkhoz markets" and "flea markets" of Soviet times are the direct historical predecessors of the post-Soviet markets. Partly they are also genetic ancestors, as these 
kolkhoz markets served as platforms from which they began to develop; the main thing is that kolkhoz markets were a carrier of ideas and the market relations in officially non-market society. Certainly, the bazaar is not the market, but the bazaar inevitably has an element of the market. It is crucial that the "kolkhoz markets" and "flea markets" were not very loved and respected in the socialist society, but they were quite legal. At the same time they served legal protection "clout" for illegal and severely punishable "speculators", "shadow businesses", "spiv" (Romanov, Suvorova, 2003) and other representatives of the illegal business.

The markets were an integral and very important part of the real socialist relations. They were a serious and ineradicable institute of Soviet socialist system despite its dubious ideological nature. Without their study our understanding of the socialist era will not be complete and adequate.

According to the official rules, the markets were the place of the primitive exchange, purchase and sale of personal belongings, sites for selling surplus from kolkhozs' gardens, an essential means of support for urban residents. Actually, the set of functions was immeasurably richer. The market was a place of the legitimate sharing and bargaining; an exchange channel and a sustaining mechanism for the urban and rural livelihoods; a ground for forming and functioning of the market mechanism for inter-regional exchange; a terminal of "shadow economy"; an embryo of "ethnic economy".

With the collapse of the socialist system of relations, including the public distribution system, markets became a main mechanism for the supply of a huge mass of people with consumer goods; a place and mechanism of formation of the mass small businesses, fostering the "crystallization" of market relations and connections. They served as an initial starting point for the beginning of the business, including "hoi polloi" of small traders and "shuttle traders". They inherited markets from the socialist past as the place of habitual and legal exchange and trade.

However, new times and new challenges have radically changed both functions of previous kolkhoz and flea markets and their place in the new emerging system of relations. Their very character has changed (new forms of ownership, new management, and new features); there was trade expansion to new sites. The old locations were inadequately small and not very well organized for new tasks. Therefore, new markets have been created in the stadiums, ruined factories, etc., where there were space, utilities, clean places in terms of organization and ownership. The old markets and flea markets have turned up to be not very large and influential part of the new system, losing the peculiarities of the Soviet organization and style.

The aforesaid facts prove the huge role of the phenomenon. It is striking in this case that it is almost not studied and was not even described in the past. In practice, this is historiographical "blank space". I know only a few works on this subject, but they are devoted mainly to the transition period of the 1990s (Il'ina, Il'in, 1998; Il'ina, Il'in, 2001; Titov, 1999). They give a snapshot of the situation of not late Soviet, but of early capitalist era, when the market was changing rapidly. The papers are significant and interesting, but the authors do not solve the problem of studying the Soviet market.

It can be assumed in this case that the Soviet market, its functions and mode of existence, its role in society were not static. It underwent a radical change: from "Sukharevka" square of Civil War (Bondarev, 2015) to "kolkhoz markets" and "flea markets" during era of stagnation. But all these facts, again, do not fill the gap; these facts stayed only in the form of myths and legends in the historical memory. 
One can wonder about the reasons. Socialist era is one of the least understood and thought over in the Russian history. And the reason cannot be reduced to the authorities' pathological passion of keeping secrets, a total closedness of society. The opening of the archives, free access to the concealed information of the Soviet era now would not allow us to form an adequate judgement about many key phenomena and processes. One of the reasons is mandatory normative description of social reality. What was not supposed to exist, was not described in the documents and written sources in general. There was a vivid language of euphemisms, omissions, allusions, "mutual winks" and informal practices. Perhaps such an ideologically dubious object as the market was taboo to study. And even if there was no explicit prohibition of the study of socialism backwoods, the related themes signified conversation stoppers.

So now it is extremely difficult to study the markets due to the acute shortage of sources and deliberate incompleteness and one-sidedness of them. The object passed away finally, leaving little information to track, which is frightening. Furthermore traces of information are obviously one legged. Due to the ideologically questionable nature of the object a lot of information not only was hidden, it was not put down on paper at all. Sure enough, there is an urgent need to "open the archives" of the Soviet era, to extract the maximum possible from them. After all, "kolkhoz markets" and "flea markets" were legally documented, they had accounting and personnel departments, trade unions and party cells. Naturally, the orders, reports, protocols must have been kept. The archives of law enforcement and legal proceedings inspire some hope to find some documents. But you must understand that this is an "official" side of the phenomenon, which should be seen. The shadow side of the market, their routine practice, their real lives, real functions, scales and forms of economic activity may be reflected in the archival documents by accident, in a sketchy form, indirectly, or not reflected at all. There is a slim chance of eyewitnesses, but for obvious reasons this source of information will disappear soon.

\section{Genesis of post-Soviet markets}

It is difficult to imagine Russian city life of the late $20^{\text {th }}$ century associated with rapid change and at the beginning of the $21^{\text {st }}$ century without a huge network of retail markets. By V.V. Radaev's definition (Radaev, 2007, 54-55), "retail markets" represent a group accommodation of trading areas of non-store format. Regardless of whether they are located in a covered structure or in an openair location, these markets are an association of retail properties, located in not permanent structures". These structures include a pavilion, a kiosk, a vending kiosk, trade stalls, and doorto-door sales.

The new quality and the new role of open markets in the post socialist era were the result of the cumulative impact of a number of factors. The socialist system of production and distribution of consumer goods collapsed. At the same time there was an immediate need in an alternative support system. A huge number of people were thrown out of the public sector, once lost means of living. There was an actual devaluation of their previous life strategies, status, qualifications, while market relations were legalized and the borders opened.

Markets, market activities became a means of survival, the area of gaining new resources and status, self-development territory. Here it was possible to start almost from scratch, with no initial capital, social connections, market experience and system of values. Undoubtedly, these were illegal and semi-legitimate professional entrepreneurs of the old regime, who got a great head start. Then the markets saw the inflow of 
highly educated citizens, ready to geographical and social mobility.

A "hunger" for commodities in combination with open borders gave rise to a mass phenomenon of shuttle trading. "Shuttle trade" played a huge, perhaps even a decisive role in supplying the population at a critical moment of collapse of the socialist economy. For hundreds of thousands of people employed in it, it became a school of entrepreneurship, an incubator for small and medium-sized businesses. There were formed colossal trade cross-border flows, almost not fixed in the official statistics, by the way.

It is obvious now that this is clearly undervalued and under-studied phenomenon. Although, of course, the lack of studies is incomparable with the under-studied nature of the Soviet markets. We study the history of the phenomenon, which is naturally associated with the disasters suffered by Russia in the $20^{\text {th }}$ century (Davydov, 2002; Shcherbakova, 2008). Much work has been done to study the extent of "shuttle trade", its role and quite complex organization in the national economy and individual regions; the researchers have described the different types of shuttle traders and their motivations and strategies (Iakovlev, Golikova, Kapralova, 2006; Ryzhova, 2005; Ivanov, Komlev, Tolchinskii, 1998; Klimova, 2006; Klimova, 2008; Klimova, Shcherbakova, 2008; Maiorov, 2002). However, generalizing monographic studies are still waiting in the wings.

The scale of shuttle trade generated a demand for infrastructure, particularly for the stable stationary platforms, terminals of creation and distribution of commodity flows. The process of their formation started in the former kolkhoz markets and flea markets. However, the resource was overflowed instantly. And then from the ground up, from scratch there were created new sites - in the stadiums, wastelands, areas and departments of bankrupt factories, plants, etc. The key to success was large and comfortable space, and also communal and transport infrastructure, convenient location, definite legal status. These were not only new sites, but also a new style and new mechanisms of organization, power and control.

There was a rapid transition from the street vendor trade to the trade from counters, cargo transporters, in hangars. The markets were equipped with serving infrastructure and related services. The safety was of particular importance. There was a rapid way from the initial chaos and individual efforts (where the market was simply a platform for trade) to the system, from the conglomerate of individual traders to structuring, networking, parallel institutions of power and control, to the market as complex and organized body. Individual and acting at their own risk shuttle traders quickly integrated into the system (under different conditions).

When the restrictive actions of the authorities, the competition of large companies, which created an efficient and competitive import and large wholesale system, gradually replaced the shuttle traders, the markets adapted to this situation, too. As they were initial and final terminals, they also were a part of the changing system, changing themselves as well.

\section{Part of cross-border networks}

The post-Soviet markets were not a conglomerate of autonomously functioning trade subjects. A symbiosis with shuttle traders made them an interface for inter-regional and international trade exchanges. Almost immediately, they became a part of international networks, along which there were enormous flows of goods, money, people, information; where the business cultures meet together and enhanced, where the rules, regulations and sanctions for noncompliance formed and functioned effectively. 
In general terms, this system consisted of three major elements. Commodity flows began to form in the "initial terminals", particularly in China and Turkey. They boosted a notable sector in Turkey and China (Kapralova, Karaseva, 2005). There appear "Russian markets" in Beijing (Guzei, 2014), Istanbul, specialized cityterminals in China, Manchuria (Fedorova, 2014), Suifenhe, Heihe (Ryzhov, 2003; Ryzhova, Ioffe, 2009; Zhuravskaia, 2014; Biie, 2014), the transit markets in Kyrgyzstan as an option (Rakhimov, 2009). The functions of the terminals included tracking evolution of demand in Russia, the formation of orders for local manufacturers, wholesale and retail trade, the formation of small wholesale lots, consulting services (in Russian "pomogaiki"), various services (restaurants, saunas, prostitution).

The second element was shuttle traders, followed by specialized firms, which eventually replaced them. Their function was to purchase goods,makeconsignments, providetransportation, customs clearance (for companies), wholesale trade in Russia.

And finally, the markets in Russia and partly in Eastern Europe as the support base for new trade and supply chains. Their most notable, but conceivably not the main function was retail and small wholesale to direct consumers. These direct consumers were enormous human flows, sometimes reaching tens of thousands of people a day. And although the amount of purchases for most of them was not great, but summing it up, it gave gigantic turnover. Customers, especially low-income people, were attracted by the low prices, the ability to negotiate, select goods. They were impressed by very democratic style of communication, which allowed one to feel free and relaxed.

However, the main function of the large markets was logistics. At the Irkutsk market "Shanghai" traders not only from nearby towns, but also from Ulan- Ude and Chita regularly made their purchases in bulk. The scale of this business is known now due to the information that became available after the closure of Cherkizovsky market in Moscow. It gave work up to 100 thousand people, $70-80 \%$ of whom were citizens of China. According to Chinese newspaper "Dongfang Zaobao", at the market there were left items worth about five billion dollar, owned by Chinese traders (Gabuev, Kozenko, 2009).

Global character of the phenomenon makes studying post socialist markets in their complex, making the task of comparative research absolutely necessary. However, there arises the same problem as in Russia, the phenomenon is very poorly understood, a huge deficit of individual cases, the lack of a systematic, integrated vision of the problem. The author has read the papers on the "Russian Market" in Beijing, about city-terminals in Manchuria and Heihe, but has not come across research texts about their counterparts in Turkey. As for cross-border markets in Kyrgyzstan there is an article on Dordoi, but strategically important market Karasu remains "blank space". There are several works about the former Soviet Union markets outside of Russia: papers on the market in Odessa (Humphrey, Skvirskaia, 2009), R.A. Spector wrote about Almaty (Spector, 2008), there is a monograph by P. Hohnen about Vilnius (Hohnen, 2004). This gives at least a minimal opportunity to compare the situation in different countries of the former Soviet Union. It is extremely important that there was a seminar on post-socialist markets in Eastern Europe ("Post-socialist bazaars: Markets and Diversities in ex-COMECON countries". International Conference, 23-24 February 2012 in Göttingen). There are several articles on this topic (Van der Velde, Marcinczak, 2007; Sik, Wallace, 1999; Huwelmeier, 2013). However, given the scale of the problem and its significance, these articles 
are not enough, what is more, the problem is studied with a huge delay.

\section{Role in economic and social life}

The markets became a site and a testing ground for forming a stratum of large-scale small businesses. The markets drew up huge commodity and cash flows, concentrating a wide variety of interests. Here was a meeting of formal and informal economies. Finally, regular visits to the markets were included in the strategy for the economic survival of the main stratum of citizens.

At the round table "Labor Migration and Retail Markets" (2007) Senator Vladimir Slutsker noted that there were about 6,000 retail markets in Russia, employing 1.2 million people. "Markets fully dressed up, shoe, feed and give drinks to the entire population of Russia... Most of the potential buyers at the markets are poor Russians, so any ill-considered action to regulate the markets could significantly undermine their standard of living" (Moskovskoe biuro, 2007).

Having become the school of business the markets generated new and large social and professional groups with their own way of life, a type of behavior, with particular subculture (Grigor'eva, 2008). There are examples of how they could vigorously and in an organized form defend their corporate interests. Struggling against the decision of the municipal authorities about the closure of the Irkutsk market "Shanghai", local traders banded together in their own trade union, held several public events and even sent a message to the president. To protect their interests they founded a newspaper "East Siberian Shanghai", which for almost a year waged a vigorous fight against the decision on the closure of the market. The market was not saved, but the authorities demonstrated clearly that the market is a real force to be reckoned with and seek mutual compromise.
The mass character of market traders, their origin from different social classes and social strata, maintaining close ties with them - all these contributed to the societal legitimating the previously unacknowledged market values , habits, lifestyle, understanding of the law and the need for market trading (Ul'iankina, 2014; Orlova, 2011).

\section{"Ethnic Markets" and "ethnic entrepreneurship"}

Post socialist markets emerged in the context of open borders, transition to market relations in symbiosis with the cross-border shuttle trading; they have become logistics centers for the promotion of imported consumer goods and food. An additional and very important compound was unprecedented in the history of Russian crossborder labor migration. All these factors have created a phenomenon that people labeled as "Chinese", "Caucasian" or "Kyrgyz' markets and shopping arcades.

In the research literature they are most often referred to as "ethnic markets". The conventionality of this terminology is obvious: people of different nationalities and citizenships work at these markets and providing a variety of services. All of them are in one way or another ethnophors, but we habitually use the adjective "ethnic" with a view of minorities only. The terms should not cause any debates, rather there should be some agreements and as soon as they become part of the daily speech, nothing remains but to use them with the appropriate caveats and explanations.

The most common phenomenon of this series was "Chinese markets", which appeared in many large and small towns of eastern Russia, and often in the cities of the European part of the country. They were called Chinese by the population of these cities, where markets were often labeled and titled in relation to geographical 
origin of sellers ("Shanghai" or "shankhaika", "Manchuria", "Chinese market" in Irkutsk, for example). Sometimes the names were neutral in the ethnic sense, but there was every reason to consider them Chinese.

This estimate is based on the following factors: Chinese goods, Chinese traders, the Chinese capital, Chinese management (usually behind the scene). In fact, this referral states not the predominance of Chinese traders, but the type of relationships set by Chinese goods). This type of relationship includes the cheapness of goods, their not very high quality, the ability to make bargains, the style of behavior of the Chinese traders, their business culture. Over time the "Chinese" referral becomes a brand, a trademark; and this understanding goes far beyond the ethnic field, determining the economic and even social parameters. Then appeared a conscious need, as business technology, in forming the "Chinese face" of the market - through a simple set of signs (name, Chinese-like design, etc.). Chineseness became a specially produced good for sale, and, apparently, it is not accidental that a new shopping mall built on the site of the demolished famous Irkutsk "Shanhai" market was named "Shanghai City Mall".

This suggests the possibility of situations where the market could be labeled as "Chinese" without apparent predominance of Chinese traders. This is evidenced, in particular, by a little study of A. Okhotnikov on the Chinese market in Novosibirsk (Diatlov (ed.) 2009, 266-269). The material for analysis is a fair bit, and we can only assume as a hypothesis that the Chinese goods moved to the markets in the cities of Western Siberia and the Urals through the Central Asian states. It must have been more convenient and profitable to use the services of these countries and their business networks.

By the way, Turkey, at a time comparable to China in terms of goods manufactured for sale by shuttle traders did not participate in the process of their transportation and sales in Russia. Turkish goods were coming without Turkish shuttle traders and without Turkish capital and management. As a result, Turkish goods did not generate the "Turkish" markets.

As opposed to this, Chinese goods created not only Chinese, but also Kyrgyz markets. There is almost no relevant research, but the available observations show that just in a few years, Russia saw numerous (especially considering the small population of Kyrgyzstan) Kyrgyz communities (Diatlov, Grigorichev (eds), 2013; Varnavskii (ed.), 2013). For us the important thing is that, unlike the Tajik and Uzbek migrants, they actively entered the business on the open market and won quite a strong position there. In most of the Siberian and Far East cities there appeared the Kyrgyz markets or Kyrgyz rows of shopping stalls.

And here we come to the extremely important question of the role of migrants in the activities and the structure of markets, especially ethnic ones. The role is not just noticeable here; it is so great that it has become one of the essential characteristics of the phenomenon. And it is not connected just to the number of people involved. Of course, a Chinese product itself can be an important sign, a symbol of the relationship and status. But when there are people behind it, the problem acquires more dimensions.

Migrants have a presence in the background of the Soviet markets. In 1960-1980s in the "kolkhoz markets" there was a steady, fairly large and very noticeable stratum of people from the Caucasus. They worked mainly in distribution and sale of vegetables, fruits, flowers, produced in their own countries. The extent and nature of their regular activities allow us to speak about them as a professional business, semi-legitimate from the point of view of the authorities and not approved of by public morality. 
Then there was formed an "image of a Caucasian" - a person, who is not just distinguished by a special culture and behavior, external appearance, but also being a symbol of "commercialism" in the moral categories of those years (Diatlov, 2010). We can assume that the usual ethical categories became a way of stereotyping socio-economic effects. Imposed by the state and accepted in the society as a whole, view on ethnicity as a phenomenon ("nationality" in terms of that time), namely, not a cultural phenomenon, but as determined by the "blood" and origin, provoked the emergence of the racial connotations in this stereotype. "Caucasians" were isolated as a group and treated as a group, embodying not only the unusual cultural norms and practices of conduct, but also a type of economic behavior condemned by public morality.

With the collapse of the Soviet Union and the collapse of the socialist relations Russia saw a flood of cross-border migrants, many of them came to the markets in search of jobs and economic opportunities. Shuttle traders were originally of different nationalities and citizenships Russian, Ukrainian, Chinese, Kyrgyz, etc. The predominance or the prominent role of certain groups was determined not so much by what is sometimes called "ethnic predisposition", but by the very situation and economic feasibility. After all, the strategy of shuttle trading itself, relevant practices, skills, infrastructure were borrowed by former Soviet citizens from the Poles. No wonder many Russian markets in China and Turkey were originally Polish. Open markets have become a place and a mechanism for economic and social integration of cross-border migrants, the area of concentration of their economic activities and social organization.

All these makes a question posed in the ongoing discussions about the "ethnic economy" extremely urgent and important (Aldrich, Waldinger, 1990; Waldinger, Aldrich, Word,
2008; Min Zhou 2004; Radaev, 1993; Brednikova, Pachenkov, 2000): whether collective or individual strategies are selected by workers as a means to achieve economic success in the markets? If the strategies are collective, what is the basis for formation of their groups? Is their behavior in the markets determined by considerations of economic expediency or group loyalty? Are these motives complementary or mutually exclusive? What is the role of the ethnic factor in their marketing activities, and what is its role in the way of life in the host society? Do such workers find it possible to use the network of intraethnic (intragroup with ethnic orientation) relationships, relations of cooperation, mutual dependence and support as a business resource?

Regarding these issues there are opposite hypothesis. One of them is that the trader is governed by purely economic motives and incentives, so ethnic, community and other kinds of group loyalty do not determine the choice of trading strategy and practices. There is also quite a contrary point of view, i.e. a model of trader's behavior is predetermined by the belonging to their own ethnic group and their group loyalty.

To justify or deny these hypotheses in relation to modern Russia the researchers are sorely lacking in empirical data. It seems however, that the answer to this question may be different in different circumstances and contexts. Above all, such an approach can get us away from recognition that the group communication and loyalty (community, family, clan, ethnic, or any labeled as ethnic) can be a powerful market and economic resource. The experience of "commercial ethnic minorities" in traditional society shows this trend clearly (Diatlov, 1996). No matter what, the specifics of the post-socialist markets lies in the fact that they are an institution of the modern society rather than community. Therefore, direct analogies are impossible here. But asking the question about them seems not 
only a correct action, but also very important and promising.

The use of heuristic approach of "ethnic economy" allows us to revert to the issue of what "ethnic markets" are. The prevailing understanding is defined by views in the host society. This understanding comes from the absolute presumption that "Chinese market" is not only traders (including those of Chinese origin and nationality), but it is a group of Chinese people whose economic behavior, business practices are human loyalty are determined by belonging to the Chinese nation. The host society sees separate groups in the markets and perceives individuals as their organic part.

The research task is, apparently, to put a question mark here and try to answer the questions on the basis of specific situations and cases only. Moreover, it is highly desirable to have certain dynamics. Are "ethnic markets" a site where motivated primarily by profit individuals act? Or are "ethnic markets" involved in activity of groups organized by ethnic belonging? Or even if they are not based on ethnicity, they are ethnically marked? Does one suggestion contradict the other? Are the "ethnic markets" simply trading platforms; do individual traders act at their own risk, or are there established stable and effective internal mechanisms of regulation, control and power? If so, are they ethnic, or clan and ethnically marked? Is the power determined by the availability of economic resources and power? Is there a division of labor along ethnic lines? It should be borne in mind that there is a pronounced phenomenon of ethnicizing migration processes in the modern Russian society. In the modern Russian society there is a situation, when the socio - economic processes (e.g., migration) are routinely described in cultural terms, including ethnic ones. When the logic and practice of one migrant's behavior is attributed to the whole ethnic group.
There are a lot more questions than answers. The number of existing researches (very small and fragmentary) does not give much reason for broad generalizations and conclusions. However, the experience of studying Irkutsk markets suggests (without extending this experience a priori for all "ethnic markets") that these markets are not simply shopping areas and business entities. The market system also led to the division of labor (including, one by ethnic belonging); the inner mechanisms of the organization and control; social networks, including ethnic ones.

\section{Context. Markets}

\section{in the urban environment}

The markets are more than just a place where goods and money pass from hand to hand. They are a meeting place for a permanent contact between people of different cultures; a location and a mechanism of getting used to the phenomenon of ethnic and cultural diversity as the norm. They have become an integral part of the urban space as a personification of not only trade and market relations, but also a special cultural phenomenon. This special character requires a separate study. But perhaps it is no accident that in the TV series "Cherkizon. Disposable People" (2010) the market appears as a certain incarnation of stalker "zone of alienation". They are a strange dangerous, but at the same attractive and exotic place. Most likely, this is an exaggerated view, artistic overstatement. It is unlikely that a normal market visitor feels a sense of risk and danger, but a feeling of wary detachment is clearly present.

The markets were not isolated institutions in the urban environment. Around them it is natural to see the most diverse forms of service infrastructure and entertainment. It is no coincidence, for example, that in the market area, in "ethnic" markets in particular, there is a high concentration of a various enterprises, providing 
"the ethnic catering". Small street traders also flock here, closer to the existing streams of buyers (Ivleva, 2010; Riazantsev (eds) 2004). The migrants also prefer to settle closer to the markets, forming here though still vague, not very distinctive, but obviously ethnic clusters.

The markets are a constant concern of the city authorities, being an important source of resources and life-support mechanisms, and at the same time - a cause or reason of various problems and conflicts. The problems of transport, sanitation, slums in the surrounding areas, tax evasion and violations of immigration law, the increased level of crime, corruption make the authorities and public have a fair sense of weak accountability and controllability of the strategically important for city facilities.

Therefore, "ethnic markets" are constantly in the public eye; they are the subject of regular debates in the press and on the Internet. And this attention is often far from friendly.

\section{Conclusion. "The Dying Breed and the Problem of its Reconstruction}

Post-Soviet markets are going into the past, along with the post-Soviet transitional era. By definition, this phenomenon is temporary and transitory. The very definition of "post-socialist", or post-Soviet implies time of transition and exhaustion. This is the fundamental difference of these markets from the very oriental bazaars, with their long history and their rootedness in tradition and rich culture. They can be transformed in modern retail formats such as hypermarkets and malls, but preserving the tradition and continuity.

Post-socialist markets are a way of economic activity and the mechanism of survival for the people who grew up during official banning of market relations because of their low status. Postsocialist markets were created by originally nonmarket people, yet with the abundant involvement of previously existing market elements. They began to develop a machine of market and business behaviors, special ethics and values. Having created all this, they have to die out by convention, go away as a transitional type of relationships.

Open-air markets are retreating under the pressure of competition and cost-effective modern trade formats, like retail networks, trade galleries, hypermarkets, malls. Regular foreign business coupled with the tightening of customs policy squeezed shuttle trading, being the key to the stability and prosperity of openair markets. Economic factors of extrusion and marginalization of open-air markets were complemented by the authorities' policy. It is enough to recall at first partial and then complete prohibiting foreigners from trading on open-air market, the decision of closing open-air markets in large cities (Mikhailova, Tiuriukanova, 2009).

Definitely, open-air markets, including ethnically marked ones will not disappear completely. Its niche will stay in the format of "flea markets" (Pachenkov, 2004), food markets, and to some extent, wholesale and retail markets, too. "Ethnic business" is unlikely to disappear as it effectively masters modern formats now, responding effectively to all prohibitions and restrictions. However, the time of prosperity of open-air markets is left behind unless, of course, the country suffers a new political and economic cataclysm.

Post-Soviet markets in their original form and with their previous roles have become a part of history. The possibilities of studying them in real time have reduced radically, thus narrowing the field survey area. The most important thing is that now we can study not the same markets that used to be a token of the almost finished Soviet era. From social anthropologists and specialists in economic sociology the object of study passes to historians. 
This gives a reason to draw some conclusions. They are not too encouraging. It is needless to say here the situation is not such a failure, in comparison to the study of Soviet markets. Nevertheless, the attention of researchers to post-socialist markets in general, and "ethnic markets" in particular, is a lot less than the value of these phenomena for the transitional era.

There is no statistics or quantitative calculations across the country and by individual cities and regions regarding the turnover, profitability, goods and cash flows, the dynamics of taxes and fees, the number of trading places and their participants. There is no generalizing and even fragmentary information on the open-air market share in the total turnover of the country. The share of these markets in the development of urban communities is poorly identified, we know very little about their inner life, the system of relationships, relations of power and control. We can only hypothesize about their place in global systems. The problem of complex analysis of "ethnic markets" has not been solved, not even of studying these markets as a "thing in itself" (which is also useful and necessary), also of studying these markets as an integral part of the cross-border systems and systems of relations in the city.

In general, it is easier to describe what is available. Due to breakthrough works by V. Radaev (Radaev, 2006; Radaev, 2007) now we understand the nature and character of the phenomenon of open-air markets more clearly than ever. There are good results in studying shuttle trading, the dynamics of development of small and medium-sized businesses. The authors gathered considerable narrative material, made interesting and important observations and generalizations. This gives hope for the emergence of large-scale monographic works in the near future.

But "ethnic markets" are studied only by individual examples. A series of publications about them enlists small but very informative articles about Ussuri market center in Ussuriysk (Trenin, Vitkovskaia, 1999; Gel'bras, 2001). In 2005 , the first article, which opens a series of works about the "Shanghai" Chinese market, or colloquially "shankhaika" in Irkutsk was published (Diatlov, Kuznetsov, 2005). Within the framework of research project actually beginning with publishing of this article, we published articles about the markets in Irkutsk, Novosibirsk, Blagoveshchensk, Yekaterinburg (Diatlov (eds) 2009; Burnasov, 2007; Diatlov, Grigorichev (eds), 2014). A number of articles on the specifics of cross-border trade and the role of open-air markets were published by N. Ryzhova and T. Zhuravskaia (Ryzhova, 2008; Zhuravskaia, 2011; Zhuravskaia, 2012). A scandalous closure of giant Cherkizovskii market in Moscow caused a lot of publications in mass media, but this event did not become a pretext for research (except for Alexandrova, 2010).

That is, in fact, almost all. There are few cases and few markets have been the object of research attention. Although these data are very important, they are insufficient for the comparativeresearch, for serious generalizations. A plenty of the most important and incredibly interesting problems are still waiting to be studied. If they would be studied at all.

"The dying breed"...

\section{References}

Aldrich, H. E., Waldinger, R. (1990). Ethnicity and Entrepreneurship, In Annual Review of Sociology, (16), 111-135. 
Aleksandrova, M. (2010). Zakrytie "bol'shogo rynka" ili ukhod ot "serykh tamozhennykh skhem" [Closing the "big market" or departure from the "quasi-legal customs schemes"]. In Problemy Dal'nego Vostoka [Problems of the Far East], 4, 65-75.

Biie, F. (2014). Sovremennost' v prostranstvennom izmerenii: otkrytye rynki, germetichnost' i vertikal'nost' $v$ dvukh prigranichnykh gorodakh Rossii i Kitaia [Modernity in the spatial dimension: open markets, tightness and verticality in the two border cities of Russia and China], In Ekonomicheskaia sotsiologiia [Economic Sociology], 15 (2), 76-95.

Bondarev, S.V.(2015). Rynochnaia torgovlia v Petrograde v 1917-1921 [Retail trade in St. Petersburg (Petrograd) in 1917 - 1921]. Dissertation of Candidate of Historical Sciences, St. Petersburg, 221 p.

Braudel, F. (1988). Material'naia tsivilizatsiia, ekonomika i kapitalizm XV-XVIII vv. Igry obmena [Material civilization, economy and capitalism in XV-XVIII centuries. Games of exchange], 2, Moscow, Progress, $632 \mathrm{p}$.

Brednikova, O., Pachenkov, O. (2000). Etnichnoct' “etnicheskoi ekonomiki” i sotsial'nye seti migrantov [Ethnicity of "ethnic economy" and social networks of migrants]. In Brednikova, O., Voronkov, V., Chikadze, E. (eds.) Etnichnost' i ekonomika: sbornik statei po materialam mezhdunarodnogo seminara [Ethnicity and economy: collection of papers of international seminar], Centre for Independent Social Research, St. Petersburg, 47-53.

Burnasov, A. (2007). Kitaiskii rynok kak logisticheskii tsentr: na primere rynka "Taganskii riad" v Ekaterinburge [The Chinese market as a logistics center: a case study of the market "Tagansky Ryad" in Yekaterinburg]. In Diatlov, V.I. (eds.) Migranty i diaspory na Vostoke Rossii: praktiki vzaimodeistviia s obshchestvom i gosudarstvom [Migrants and diasporas in Eastern Russia: the practice of interaction with the state and society]. Moscow, Irkutsk, Natalis, 68 - 80 .

Davydov, A.Iu. (2002). Nelegal'noe snabzhenie rossiiskogo naseleniia $i$ vlast'. 1917-1921: Meshochniki [Illegal supply of the Russian population and the authorities. 1917-1921: Profiteers]. St. Petersburg, Nauka, 341 p.

Demoscope Weekly, 2009, 367 - 368, available at: http://demoscope.ru/weekly/2009/0367/s_map. php.

Diatlov, V.I. (1996). Predprinimatel'skie men'shinstva: torgashi, chuzhaki ili poslannye Bogom? Simbioz, konflikt, integratsiia v stranakh Arabskogo Vostoka i Tropicheskoi Afriki [Entrepreneurial minorities: shopkeepers, strangers or those sent by God? Symbiosis, conflict, integration in countries of the Arab East and tropical Africa]. Moscow, 1996, 256 p.

Diatlov, V.I. (2010). Transgranichnye migrant v sovremennoi Rossii: dinamika formirovania stereotipov [Cross-border migrants in modern Russia: the dynamics of the formation of stereotypes], In Politia. Analiz. Khronika. Prognoz [Politiia. Analysis. Chronicle. Forecast], 3-4, 121-149.

Diatlov, V.I. (eds.) (2009). Transgranichnye migratsii i prinimaiushchee obshchestvo: mekhanizmy $i$ praktiki vzaimnoi integratsii [Cross-border migrations and the host society: mechanisms and practices of mutual integration]. Yekaterinburg: Publishing House of Ural State University, 396 p.

Diatlov, V.I., Grigorichev, K.V. (eds.) (2013). Pereselencheskoe obshchestvo Aziatskoi Rossii: migratsii, prostranstva, soobshchestva [Resettlement community of Asian Russia: migrations, spaces, communities]. Irkutsk, Ottisk, 624 p.

Diatlov, V.I., Grigorichev, K.V. (eds.) (2014). Tema Focus: Ethnicity in the urban space : from Soviet to post-Soviet, In Izvestiia Irkutskogo gosudarstvennogo universiteta. Seriia "Politika.

$$
-809-
$$


Religiovedenie" [Proceedings of the Irkutsk State University. "Politics. Religious Studies] 10, $5-250$.

Diatlov, V.I., Kuznetsov R. (2005). "Shankhai” v tsentre Irkutska. Ekologiia kitaiskogo rynka ["Shanghai" in the center of Irkutsk. Ecology of the Chinese market]. In Diatlov, V.I., Panarin, S.A., Rozhanskii, M.Ia. (eds.) Baikal'skaia Sibir': iz chego skladyvaetsia stabil'nost' [Baikal Siberia: what constitutes stability]. Moscow, Natalis, 166-187.

Dotson, F., Dotson, L.O. (1968). The Indian Minority of Zambia, Rhodesia and Malawi. New Haven: Yale University Press, 444 p.

Endres, K.W. (2013). Traders, Markets, and the State in Vietnam: Anthropological Perspectives. In ASEAS - Austrian Journal of South-East Asian Studies, 6(2), 356-365.

Fedorova, K.S. (2014). Man'chzhuriia: gorod na eksport [Manchuria: the city for export]. In Prigranichnyi urbanizm: imperskaia i postimperskaia praktiki [Border urbanism: imperial and post-imperial practices]. Ulan-Ude, Publishing House of the BSAA named after Filippov V.R., $126-$ 151.

Gabuev A., Kozenko, A. (2009). Kitai torguetsia za Cherkizovskii rynok [China is bargaining over the Cherkizovsky market]. Kommersant, 131, July, 22.

Geertz, C. (2004). Bazarnaia ekonomika: informatsiia i poisk v krest’ainskom marketing [Bazaar economy: information and search in the peasant marketing]. In Zhurnal sotsiologii i sotsial'noi antropologii [Journal of Sociology and Social Anthropology], 7(3), 153-160.

Gel'bras, V.G. (2001). Kitaiskaia real'nost' Rossii [Chinese reality of Russia]. Moscow, Muravei, $320 \mathrm{p}$.

Grigor'ieva, I.N. (2008). “Rabota, zhizn', vtoroi dom...”: zhiznennye miry torgovtsev rynka pod otkrytym nebom ["Work, life, second home...": life worlds of the open-air market sellers], In Fol'klor malykh sotsial'nykh grupp: traditsii i sovremennost' [Folklore of small social groups: traditions and modernity]. Moscow, State republican center of Russian folklore, 145 - 157.

Guzei, Ia.S. (2014). "Rasha-taun" v tsentre Pekina: rossiiskaia etnizatsiia vostochnogo rynka ["Russia-town" in Beijing centre: Russian ethnization of the eastern market], In Izvestiia Irkutskogo gosudarstvennogo universiteta. Seriia "Politika. Religiovedenie" [Proceedings of the Irkutsk State University. "Politics. Religious Studies], 10, 154 - 165.

Hohnen, P. (2004). A market out of place? Remaking economic, social, and symbolic boundaries in post-communist Lithuania. Oxford; N.Y., Oxford Univ. press, 164 p.

Humphrey, C., Skvirskaia, V. (2009). Trading places: Post-socialist Container Markets and the City, In Focaal. European Journal of Anthropology, 55, 61 - 73.

Huwelmeier, G. (2013). Postsocialist Bazaars: Diversity, Solidarity, and Conflict in the Marketplace. In Laboratorium, 5 (1), 52-72.

Iakovlev, A., Golikova, V., Kapralova, N. (2006). Otkrytye rynki i “chelnochnaia” torgovlia $v$ rossiiskoi ekonomike: vchera, segodnia, zavtra (po materialam empiricheskikh issledovanii 2-1 2005) [Open markets and "shuttle" trade in the Russian economy: yesterday, today and tomorrow (based on empirical studies 2-1 - 2005). Preprint WP4/2006/05. Moscow, Publishing House of HSE, $28 \mathrm{p}$.

Il'ina, M., Il'in, V. (1998). Torgovtsy gorodskogo rynka: shtrikhi k sotsial'nomu portretu [Sellers on the urban market: finishing touches to the social portrait], In "EKO" ["ECO”], 5, 103-120. 
Il'ina, M., Il'in, V. (2001). Rossiiskii bazaar: sotsial'naia organizatsiia i marketing [Russian bazaar: the social organization and marketing]. Syktyvkar, Publishing House of the Syktyvkar State University, $196 \mathrm{p}$.

Ivanov, V.V., Komlev, Iu.Iu., Tolchinskii, L.G. (1998). "Chelnochnyi" biznes v Kazani ["Shuttle" business in Kazan]. In Sotsiologicheskie issledovaniia [Sociological Research], 11, 40-44.

Ivleva, I.V. (2010). Ulichnaia ekonomika v povsednevnosti perekhodnogo perioda: torgovtsy $i$ rynki $v$ Sankt-Peterburge i Leningradskoi oblasti [Street economy in everyday life of transitional era: sellers and markets in St. Petersburg and Leningrad Oblast]. St. Petersburg, Publishing House of St. Petersburg University, $264 \mathrm{p}$.

Kapralova, N.L., Karaseva, L.A. (2005). Chelnochnyi biznes v rossiiskoi ekonomike: rol' i otsenka masshtabov [Shuttle business in the Russian economy: the role and scale assessment], In Ekonomicheskii zhurnal VSHE [The HSE Economic Journal], 3, 400-411.

Klimova, S.G. (2006). Chelnoki: begstvo ot nuzhdy ili pogonia za shansom [Shuttles: escape from poverty, or the pursuit of opportunity]. In Sotsial'naia real'nost' [Social reality], 2, 26-41.

Klimova, S.G. (2008). Kontseptualizatsiia roli chelnoka ee ispolniteliami [Conceptualizing the role of shuttle trade by its participants]. [Sociological Research], 4, 52-62.

Klimova, S.G., Shcherbakova, I.V. (2008). "chelnochestvo" i gosudarstvo: etapy evoliutsii otnoshenii ["Shuttle trade" and the state: the stages of evolution of relationships]. In Gorshkov, M.K. (eds.) Rossiia reformiruiushchaiasia. Ezhegodnik. Vyp.7 [Russia being reformed. Yearbook. Ed. 7]. Moscow, Institute of Sociology, Russian Academy of Sciences, 389-405.

Maiorov, S. (2002). Chelnoki [Shuttles]. In Otechestvennye zapiski [Domestic notes], 7, 414-422.

Mikhailova, E., Tiuriukanova, E. (2009). Migranty v roznichnoi torgovle: effect zapretov [Migrants in the retail trade: the effect of prohibitions]. In Vitkovskaia, G., Platonova, A., Shkol'nikov, V. (eds.) Novoe migratsionnoe zakonodatel'stvo Rossiiskoi Federatsii: pravoprimenitel'naia praktika [A new migration legislation of the Russian Federation: legal practice]. MOM, the FMS of Russia and the OSCE. Mosciw, IT “Adamant”, 237-265.

Min Zhou (2004). Revisiting Ethnic Entrepreneurship: Convergencies, Controversies and Conceptual Advancements, In International Migration Review, 38(3), 1040-1074.

Orlova, L.V. (2011). Sotsial'noe stanovlenie malogo i srednego biznesa Rossii v regional'nom izmerenii: protsessy, struktury i instituty samoorganizatsii [Social formation of small and medium business in Russia in the regional dimension: processes, structures and institutions of self-organization]. Dissertation of Doctor of Sociological Sciences. Saransk, 296 p.

Pachenkov, O. (2004). Bloshinyi rynok v perspective sotsialnoi politiki: "bel'mo na glazu" goroda ili institut "povsednevnoi ekonomiki" [Flea market in the social politics prospect; an "eyesore" of the city, or the institution of "everyday economy"?] In Sotsial'naia politika: realii 21 veka [Social politics: Realities of the 21 ${ }^{\text {st }}$ century]. Moscow, Pomatur, Independent Inst. of Social Politics, 2, 271-314.

Radaev, V.V. (1993). Etnicheskoe predprinimatel'stvo: mirovoi opyt i Rossiia [Ethnic entrepreneurship: international experience and Russia]. In Polis [Polis], 5, 79 -87.

Radaev, V.V. (2006). Chto takoe rynok: ekonomiko-sotsiologicheskii podkhod [What is the market: economic and sociological approach]. Preprint P15 WP4/2006/7, Moscow, Publishing House of HSE, 48 p. 
Radaev, V.V. (2007). Zakhvat rossiiskikh territorii: Novaia konkurentnaia situatsiia v roznichnoi torgovle [Capture of the Russian territory: the new competitive situation in the retail trade]. Moscow, Publishing House of HSE, 54-55.

Rakhimov, R.M. (2009). Rynok "Dordoi” i migrant iz Kitaia [The market "Dordoi" and migrants from China]. In Sultanov, B.K., Lariuel', M. (eds.) Tsentral'naia Aziia i Kitai: sostoianie i perspektivy sotrudnichestva: mat-ly mezhd. Konf. [Central Asia and China: state and prospects of cooperation: Materials of Int. Conf.] (Almaty, 4 - 5 June 2008). Almaty, Kazakhstan Institute for Strategic Studies under the President of the Republic of Kazakhstan, 193 - 201.

Riazantsev, S.V. (eds.) (2004). Zaniatost' naseleniia v stikhiinoi torgovle i servise: ekonomikosotsiologicheskoe issledovanie [Employment in trade and spontaneous service: economic and sociological research]. Moscow, Nauka, $216 \mathrm{p}$.

Romanov, P., Suvorova, M. (2003). "Chistaia fartsa": sotsial'nyi opyt vzaimodeistviia sovetskogo gosudarstva i spekuliantov ["Clear fartsa": social experience of the Soviet state and speculators' interaction]. In Olimpieva, I., Pachenkov, O. (eds.) Neformal'naia ekonomika v postsovetskom prostranstve. Problemy issledovaniia i regulirovaniia [Informal economy in the post-Soviet space. Problems of research and regulation]. St. Petersburg, CISR, 148-164.

Ryzhova, N. (2008). Informal economy of translocations. The case of the twin city of BlagoveshenskHeihe. In Inner Asia, 10 (2), 323-351.

Ryzhova, N.P. (2003). Transgranichnnyi rynok v Blagoveshchenske: formirovanie novoi real'nosti delovymi setiami "chelnokov" [The cross-border market in Blagoveshchensk: formation of a new reality by business networks of "shuttle traders"], In Ekonomicheskaia sotsiologiia [Economic sociology], 4 (5), 54-71.

Ryzhova, N.P. (2005). Blagoveshchensk - forpost imperii ili zona svobodnoi ekonomiki? [Is Blagoveshchensk an outpost of the empire or a free economy zone?]. In Diatlov, V.I., Riazantsev, S.V. (eds.) Stabil'nost' i konflikt v rossiiskom prigranich'e. Etnopoliticheskie protsessy $v$ Sibiri i na Kavkaze [Stability and conflict in Russia's border areas. Ethno-political processes in Siberia and the Caucasus]. Moscow, Academic Educational Forum on International Relations, $202-227$.

Ryzhova, N.P., Ioffe G. (2009). Trans-border exchange between Russia and China: the case of Blagoveshchensk and Heihe. In Eurasian Geography and Economics, 50 (3), 348-364.

Shcherbakova, I.V. (2008). Sovetskaia predystoriia chelnochestva: ot meshochnikov do kooperatorov [Soviet prehistory of shuttle trading: from profiteers to cooperators], In Sotsiologicheskie issledovaniia [Sociological research], 4, 44-52.

Sik, E. Wallace, C. (1999). The Development of Open-Air Markets in East-Central Europe, In International Journal of Urban and Regional Research, 23 (4), 697 - 714.

Spector, R.A. (2008). Bazaar Politics. The Fate of Marketplaces in Kazakhstan, In Problems of Post-Communism, 55 (6), 42 - 53.

The Moscow Bureau for Human Rights. Chronicle of MBHR: March-April 2007, available at: http://antirasizm.ru.

Titov, V.N. (1999). Veshchevoi rynok kak sotsial'nyi institute [The market of commodities as a social institution]. In Obshchestvennye nauki i sovremennost' [Social sciences and modernity], 6, $20-35$. 
Trenin, D., Vitkovskaia, G. (1999). Vvedenie [Introduction]. In Moskovskii Tsentr Karnegi. Perspektivy Dal'nevostochnogo regiona: kitaiiskii faktor [Carnegie Moscow Center. Prospects of the Far East region: the Chinese factor]. Moscow, $101 \mathrm{p}$.

Ul'ankina, O.V. (2014). Sotsial'nyi status torgovtsev gorodskikh rynkov v usloviiakh sovremennoi Rossii (regional'nyi aspect) [The social status of urban market traders in the conditions of modern Russia (regional aspect)]. Dissertation of Candidate of Sociological Sciences Saransk, 178 p.

Van der Velde, M., Marcinczak, S. (2007). From Iron Curtain to Paper Wall: the Influence of Border Regimes on Local and Regional Economies - the Life, Death, and Resurrection on Bazaars in the Lodz Region. In Brunet-Jailly, E. (eds.) Borderlands. Comparing Border Security in North America and Europe. Ottawa: Univ. of Ottawa press, 165 - 196.

Varnavskii, P.K. (eds.). (2013). Iz Azii v Sibir', ili v poiskakh "Novogo sveta” (polozhenie trudovykh migrantov iz Tsentral'noi Azii v Buriatii) [From Asia to Siberia, or in search of the "New World" (the situation of migrant workers coming from Central Asia to Buryatia)]. Ulan-Ude, Publishing House of BSC SB RAS, 216 p.

Waldinger, R., Aldrich, H., Ward, R. (2008). Etnicheskie predprinimateli [Ethnic entrepreneurs], In Ekonomicheskaia sotsiologiia [Economic sociology], 9(5), 162-182.

Zhuravskaia, T.N. (2011). "Seryi” import na rossiisko-kitaiskoi granites: chto novogo? [“Quasilegal" imports on the Russian- Chinese border: what's new?], In Ekonomicheskaia sotsiologiia [Economic Sociology], 12(5), 54-71.

Zhuravskaia, T.N. (2012). "Kitaiskii” torgovyi tsentr vs. "kitaiskii” rynok: chto izmenilos' so vremeni zapreta na torgovliu inostrantsev na roznichnykh rynkakh (Na primere Amurskoi oblasti) ["Chinese" shopping mall vs. "Chinese" market: what has changed since the ban on the trade of foreigners on the retail markets (on the example of Amur Oblast)], In Politia. Analiz. Khronika. Prognoz [Politiia. Analysis. Chronicle. Forecast], 4, 104-123.

Zhuravskaia, T.N. (2014). Konfiguratsiia i funktsionirovanie sotsial'nykh setei v prigranichnom regione [Configuration and operation of social networks in the border region], In Prostranstvennaia ekonomika [Spatial Economics], 3, 67-94. 


\title{
Этнические рынки в постсоциалистическом транзите: роль в обществе, место в исследовательском поле
}

\author{
В.И. Дятлов \\ Иркутский государственный университет \\ Россия, 664003, Иркутск, ул. Карла Маркса, 1
}

Рынки под открытым небом стали важнейшим элементом постсоциалистического транзита. Они возникают на огромном пространстве - от Китая до Польии и Германии. Вкупе с гигантским по масштабам и значению «челночничеством» они сформировали новый феномен экономической, сочиальной, политической, культурной жизни. Рынки стали механизмом экономического выюжвания для огромного количества людей, потерявиих прежний статус и источники доходов, стартовой пломадкой для формирования мелкого и среднего бизнеса. Некоторое время они были ключевым элементом механизма снабжения, особенно для слоев с низкими доходами. В качестве начальных и конечных терминалов системы челночной торговли рынки интегрировались в глобальную систему отношений - и не только торговых, но и сочииокультурных.

Открытые рынки стали важной площуадкой экономической активности трансграничных трудовых мигрантов, механизмом их экономической и культурной интеграции. $B$ совокупности с их огромной ролью по продвижению на формирующчиеся рынки китайских и турецкких товаров, это сделало рынки в глазах городских сообществ «этническими» китайскими, киргизскими, кавказскими. В этом качестве они быстро переросли формат торговых площуадок и превратились в сложные и саморазвивающчиеся сочиильные организмы, сгустки сочиильных связей, сетей, конфликтов, механизмов власти и контроля. Вокруг них сформировались крупнейшие этнические и мигрантские кластеры многих российских городов. Они стали «местом встречи» и повседневного массового контакта, сотрудничества и конфликта представителей разных языков, культур и традиций. Рынки приобрели огромное символическое значение, олицетворяя в глазах населения массу новых форм жизни, экономических и культурных практик, способов социильных контактов и отношений.

Конец постсочиалистической эпохи подвел черту и под этой ролью «этнических» рынков. Они не исчезают совсем, но меняются сами и меняются их функции и место в сообществе. Многие закрываются, оставшиеся маргинализируются, оттесняются на окраины городов и на периферию экономической жизни. Они меняют формат - и на месте прежних оптоворозничных рынков под открытым небом появляются гипермаркеты, моль и т.д. Это не означает конец «этнического бизнеса» - он тоже перестраивается и эффективно осваивает новые форматы и новые правила игры.

Огромное значение «этнических» рынков в эпоху постсоциалистического транзита парадоксально сочетается со слабым общуественным вниманием и малой изученностью. Политические потрясения и сочиильные катаклизмы заслонили в сознании людей и $в$ представлениях исследователей эту проблему как второстепенную. Задачей этого текста являются инвентаризации, систематизации того, что мы знаем (и чего предположительно не знаем) об открытых «этнических рынках» постсоветской эпохи. Возможно, это позволит сформулировать повестку дня для дальнейших исследований.

Ключевые слова: этнические рынки, постсоциалистический транзит, челноки, этническая экономика, трансграничные мигрантыл.

Исследование выполнено при финансовой поддержке РГНФ в рамках научного проекта № 1603-00100.

Научная специиальность: 23.00.00 - политология, 22.00.00 - социологические науки, 07.00.00исторические науки. 